\title{
Students' Attitudes and Aspirations Towards Learning Science at the Secondary Stage in Kuwait
}

\author{
Ahmad Shallal Alshammari, PhD \\ Associate Professor \\ Department of Curriculum and Instruction \\ School of Basic Education \\ Public Authority of Applied Education \\ and Training (PAAET), Kuwait.
}

Naji Bader Aldhafiri, PhD

Assistant Professor

Department of Curriculum and

Instruction

School of Basic Education

Public Authority of Applied Education

and Training (PAAET), Kuwait.
Dalal Abdulrazzaq Alhendal, PhD Associate Professor

Department of Curriculum and Instruction School of Basic Education

Public Authority of Applied Education and Training (PAAET), Kuwait.

\section{Abstract}

This study explored students' attitudes and aspirations toward learning science in the State of Kuwait, specifically their perspectives on their attitudes toward learning science and the science curriculum at the secondary stage. The study used a multi-method design, with both quantitative and qualitative methods to collect the data: students' questionnaires and semi-structured interviews. The study sample was selected at random. First, a questionnaire was conducted with 441 students, then 16 students were chosen to be personality interviewed. The findings from the questionnaires and interviews indicate that most of the students hold generally negative views about learning science. They feel distanced from some of the topics and have difficulty in understanding many of the lessons, and consequently they do not enjoy studying the subject of science. The science curriculum was built up without taking into consideration the needs of Kuwaiti students. There are topics in the science curriculum that are not relevant to their daily lives or their needs. Most of the students don't want to continue studying the science specialty. This study recommends considering the perspectives of the students, and 
addressing the relationship between the content items of the science curriculum and students' needs, integrating more relevant science content in order to engage the interest of students with science relevant to their lives, needs, interests, and future education as citizens of the State of Kuwait.

Key words: science curriculum, students' attitudes, and science curriculum reform. 


\section{Introduction}

The attitudes of students towards science in schools is an important indicator for whether students will continue on to study scientific disciplines at university. In Kuwait there is a reluctance for students to study science at university, but Kuwait needs the science major (Central Statistical Bureau, 2018). The present study focused on the teaching and learning of science in the tenth grade at school (the secondary stage). The researcher chosen grade ten because after this grade in the Kuwaiti education system the student must choose to continue on either the scientific or literary path, and in Kuwait there is a shortage of students who join the scientific specialties. This can be confirmed by the number of students who study scientific specialties in Kuwait, such as medicine, engineering, energy, and physics. For example, in recent statistics from the Kuwait ministry of education, only 12 chemistry, 9 physics, 60 biology and 21 geology teachers in Kuwait are Kuwaitis (Alseyassah newspaper, 2018). The Minister of Health in Kuwait also mentioned in an interview with the Alqabas newspaper on 02.10 .2017 that the number of Kuwaiti doctors, pharmacists and nurses is 9177 , out of 38,804 non-Kuwaitis working in the country, confirming Kuwait's need for the medical and scientific education of its citizens. This demonstrates the reluctance of students to study scientific disciplines at university.

This study aims to explore in detail the Kuwait students' attitudes towards science at the secondary stage, to investigate the reasons for their lack of interest in learning science.

\section{Research problems}

The secondary stage is the last stage at school for Kuwaiti students and extends for three years. It is divided into three academic grades, from grade ten to grade twelve. In its last two years (after grade ten) this stage divides into scientific and literary sections, which students choose in the preceding year. Students in the scientific section are taught biology, geology, chemistry and physics, in addition to such 
basic subjects as the Arabic language, Islamic studies, the English language, and mathematics, which are common to the literary section also, and students can continue with university study in scientific specialities. Students in the literary section are taught psychology, philosophy, geography and history, but these students can't choose scientific specialties at university.

Many studies (e.g., Al-Daami \& Wallace, 2007; Author, 2013; Fullan, 2007; Idris et al., 2012; Khan, 2010; Reiss, 2010; Shah, 2012; van den Akker, 2003) indicate that science lessons should be made relevant to the students' interests, needs and their daily life, a lack of which may affect the students' attitudes to learning science. Weak teaching methods may be another factor in students' lack of interest. The current study investigates the students' attitudes and aspirations toward learning science and to what extent these affect their desire to continue to study in the science section.

\section{Research aims}

The study aimed at comprehensively exploring the students' views about learning science in the secondary stage in Kuwait. The particular focus was on the relationship of the science lessons to the students' needs, social culture, and daily life, and to what extent the lessons affect their attitude to learning science or to continue their study in the science section.

\section{Research questions}

4.1 What are the students' perspectives on science education in the secondary stage?

4.2 What are secondary school students' attitudes toward learning science?

4.3 Are there differences among students' attitudes according to gender? 


\section{Literature review}

\subsection{Importance of students' perspectives in education reform}

Schools have been constructed as places for students' education, curricula have been developed for their learning, and teachers are appointed to teach them. Students' central place in education should be beyond dispute. It is believed by Manefield et al. (2007) that listening to the students' voice and exploring their opinions is essential before beginning the designing and building up a curriculum, because their needs should be the foundation of the reform process. Waldrip and Taylor (1999) confirmed that the opinions and views of the students should be explored when a curriculum is designed. They state that the students' views are important in the successful process of any education reform and development, in that listening to the students will help to relate it more closely to the students' everyday life, needs and culture. In their review of the role of students in education development, Leat and Reid (2012) state that consideration of the students' views and their participation in any education reform process will assist the decisionmakers and those who are concerned with the reform process to shape their work to students' needs, which helps the planners to work out how to reform education and makes the process successful.

Some studies have gone beyond these perspectives, believing that to leave students out of the process of curriculum and education reform and ignore their needs to them lead to the failure of the who to process. Levin (2000), in his study of the role of the student in education reform, says, "Education reform cannot succeed and should not proceed without much more direct involvement of [the] student in all its aspects" (p.155). He stresses that any process of education reform, including the process of reforming the curriculum, which does not take student opinion into account will encounter problems in the future, and he considers it non-comprehensive because it has not taken into consideration the views and needs of the students. 
Moreover, some believe that taking students needs into considration and involving them in the education reform and development process will not only contribute to the success of these processes but will also produce other benefits. Manefield et al. (2007) are convinced that involving students in the development of education and listening to their views encourages their participation and discussion. This creates a feeling within the students that they are part of the educational process and enhances their confidence in themselves, which is reflected positively in their education and understanding of the lessons. Jackson (2005) stresses the same point: that giving students the opportunity to be heard in matters relating to the development of education will give the students confidence in themselves and encourage them to learn and love school. Thus, the students will feel that their voice is listened to and that they are participating in the decision-making in the development of their own education.

Many studies have emphasised the importance of linking curricula, not least the science curriculum, to the culture, needs, interests and environment of the students and to their everyday lives in helping them solve problems. In England, where the opinions of 350 students aged 16-19 were explored through interviews and questionnaires, Cerini, Murray and Reiss (2003) found that the students' views on the science curriculum revealed its strengths and weaknesses. Knowing the students' views, if the developers of the curriculum can identify the needs of the students, then they can modify the curriculum to suit these needs and link it to their everyday lives. These writers add that a system should be "put in place to ensure that decisions that affect students cannot be taken without taking student views into account" (p.19). In another study entitled 'Listening to pupils' by Reiss (2006), he highlights that it is important to listen to students so as to understand their needs and preferences in studying science, because relating the curriculum to the students' needs will contribute to their successful learning. 


\subsection{Student attitudes toward science}

The process of science education reform and student attitude based on certain student needs and interests are examined in many studies, all emphasizing that this context must be borne in mind in any science education reform process. Han (2017) mentioned that students' attitudes toward science can be improved when lessons relate to their daily life and when practical teaching methods are used, such as collaborative learning, technology-based learning, and hands-on activities. According to Nadi's (2017) study, the students' attitudes toward science can be affected by factors such as methods of teaching, the difficulty of the lessons, and enjoyment in learning. Catherine et al. (2018) suggested that science curriculum development might include lessons which encourage students to take more interest in science by making it simpler, and teaching the students how they can use science to solve challenges they come across in their daily life.

According to BouJaoude and Gholam (2013), "the socio-cultural perspectives in science education emerged as important research areas which should be taken into account while designing curricula, teaching concepts and developing views about students' understandings" (p.340). A study by Lemke (2001) indicated that the 'students' needs' context of constructing and reforming a science curriculum means viewing science and science education as human social activities carried out within cultural and institutional contexts, and this will affect passivity in the students' attitude toward science. A study by the author (Mansour, 2013) about modelling the socialcultural contexts of science education indicated that relating the science lessons to the students' needs and abilities will encourage students to regard learning science as an interesting subject. Van den Akker (2003) recommends connecting the science lessons to the students' needs, interests, society and culture, because it is important to the success of any science education reform and helps students to understand the science lessons more easily, while Fullan (2007) 
affirms the same. Waldrip and Taylor's (1999) study of the permeability of students' worldviews to their school views in nonWestern developing countries stresses the significance of taking the students' needs and culture into account when the science curriculum is designed or reformed. They found that the local culture of the students greatly affected their learning of science subjects and that this culture is relevant to life outside the school. Absorbing the content of a curriculum which is relevant to the students' lives is more beneficial to them (Waldrip \& Taylor, 1999). Reiss, too, notes in his (2002) study about reforming science education in the light of pupil views that it is important to relate the science being taught to the students' social culture, needs and their everyday life, because this will help to make the science more satisfying for them. Another benefit for reforming science education by considering student needs and the socio-cultural context is argued by Gilbert (2010) in his study about the science curriculum. Gilbert concluded that a students' needs and views-based science curriculum may not only improve student academic achievement in science education and other content areas, but also change the students' attitudes in a positive way toward science.

From the previous argument, the importance of relating science lessons to the students' needs, interests and daily life is clear. So, this study explores the students' needs, level of interest and views to investigate to what extent they want to continue their study of science, and why.

\section{Methodology}

Both quantitative and qualitative methodologies are used in this research to obtain data from multiple sources. Quantitative and qualitative research can complement one another, the former playing the part of an explorer and the latter confirming its discoveries (Gall et al., 2006). Another important aim of using mixed methods is to 
give a study value by strengthening its findings. Johnson and Onwuegbuzie (2004) argue that validity is achieved in mixed methods approaches through combining the integral strengths and nonoverlapping weaknesses of quantitative and qualitative research.

\subsection{Questionnaire sample}

The student questionnaire sample comprised 441 students (214 boys and 227 girls) from grade ten in the secondary stage at Kuwaiti public schools.

\begin{tabular}{||ccc||}
\hline \multicolumn{3}{|c|}{ Table 1. } \\
Sample distribution & according to student gender \\
\hline \hline Gender & Count & Percentage \% \\
\hline Boy & 214 & 48.5 \\
Girl & 227 & 51.5 \\
Total & 441 & 100 \\
\hline
\end{tabular}

\subsection{Data analysis}

The quantitative data were analysed using SPSS (Statistical Package for the Social Sciences). Descriptive analyses were conducted, including T-test. The means, standards deviations and percentages were calculated through descriptive statistical analysis.

\section{Research findings}

\subsection{Students' views of the science subject}

\section{Table 2}

The percentage distribution for the students' agreement with the following statements about the science subject currently taught in school

Items 


\subsection{Students' views of the science subject}

SD $\quad$ D $\quad$ A $\quad$ SA

1. Science as a subject is too hard to understand

$\begin{array}{llll}5 & 7 & 20.4 & 67.6\end{array}$

2. Science as a subject is interesting

$\begin{array}{llll}15 & 14 & 50 & 21\end{array}$

3. Science as a subject is rather easy for me to learn

$\begin{array}{llll}81.6 & 10 & 2.2 & 6.2\end{array}$

4. I like science as a subject better than most other subjects

$\begin{array}{llll}73 & 11.4 & 7 & 8.6\end{array}$

5. Science helps me solve my everyday problems

$\begin{array}{llll}45 & 20 & 15.7 & 19.3\end{array}$

6. Science as a subject has

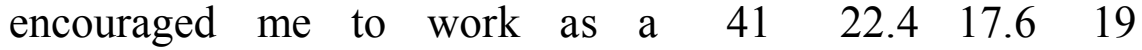
member of a team

$\begin{array}{llllll}\text { 7. I would like to become a scientist } & 71.6 & 8 & 10 & 10.4\end{array}$ Notes. Options were SA ('Strongly agree'), A ('Agree'), SD ('Strongly disagree') and D ('Disagree')

Table (2) shows the percentages in the students' responses to science as a school subject in grade ten. From the results, most of the students agree or strongly agree that science is too hard to understand, but otherwise most of them strongly agree with the statement that science as a subject is interesting. Most of the students disagree that the science solves their everyday problems and that it encourages them to work with others as a team. Most students also either disagree or strongly disagree that they would ever think of becoming a scientist. 
Students' Attitudes and Aspirations

Towards Learning Science

at the Secondary Stage in Kuwait

7.2 Students' views of science lessons

Table 3

The percentage distribution for the students' agreement with the following statements about the science lessons currently taught in school

\begin{tabular}{lllll|}
\multirow{2}{*}{ Items } & \multicolumn{2}{l}{$\begin{array}{l}\text { Percentage } \\
\text { responses } \%\end{array}$} & of \\
\cline { 2 - 5 } & SD & D & A & SA \\
\hline
\end{tabular}

8. I understand most of the information in science lessons

9. I like the current science lessons

$\begin{array}{llll}51 & 31 & 10.7 & 7.3\end{array}$

10. I like science lessons because they relate to my life

$\begin{array}{llll}63 & 22.1 & 3.1 & 11.8\end{array}$

11. I don't like the current science lessons

$\begin{array}{llll}66 & 21 & 5 & 8\end{array}$

12. The current science lessons are too hard

$\begin{array}{llll}6.3 & 4 & 11.7 & 78\end{array}$

13. The science lessons are boring

$\begin{array}{llll}11 & 12.8 & 10.2 & 66\end{array}$

14. The science lessons teach me new things

$\begin{array}{llll}37 & 28 & 17 & 18\end{array}$

15. The current science lessons should be more practical

$\begin{array}{llll}10 & 6 & 32 & 52\end{array}$

16. The current science lessons should be more technology based

$\begin{array}{llll}17 & 20.8 & 33.1 & 29.1\end{array}$

Notes. Options were SA ('Strongly agree'), A ('Agree'), SD ('Strongly disagree') and D ('Disagree')

The results in Table (3) show that most of the students either agree or strongly agree that they do not understand most of the current science 
lessons and think these lessons are too hard. Most either agree or strongly agree that they do not like the current science lessons and think that they are boring, irrelevant to their daily lives and do not teach them new things. Most of the students strongly agree that the current science lessons should be more practical.

\subsection{Students' reasons for learning science}

\section{Table 4}

The percentage distribution for the students' reasons for learning science

\begin{tabular}{|lcccc|}
\hline \hline \multirow{2}{*}{ Items } & \multicolumn{3}{c}{ Percentage } & of \\
& responses \% & \\
\cline { 2 - 6 } & SD & D & A & SA \\
\hline 17. To use it in my daily life & 71 & 15 & 9 & 5 \\
18. To use it to solve my problems & 66 & 20 & 5.3 & 8.7 \\
19. To be a scientist in the future & 68.2 & 13.4 & 7 & 11.4 \\
20. To pass the exams & 8.2 & 3.2 & 18.5 & 70.1 \\
\hline Notes. The options were SA ('Strongly & agree'), A ('Agree'), SD \\
('Strongly disagree') and D ('Disagree') & & & & \\
\hline
\end{tabular}

The results shown in Table (4) are that most of the students study science in order to pass the exams. Also, most of them feel that they would not use science to help them in everyday life or to solve everyday problems. 
7.4 Students' views on the learning activities used in science lessons

\section{Table 5}

The percentage distribution for the students' views about the learning activities which they usually use to learn science in science lessons

\begin{tabular}{|c|c|c|c|c|}
\hline \multirow[t]{2}{*}{ Items } & \multicolumn{4}{|c|}{$\begin{array}{l}\text { Percentage } \\
\text { responses \% }\end{array}$} \\
\hline & SD & D & $\mathbf{A}$ & $\mathbf{S A}$ \\
\hline $\begin{array}{l}\text { 21. Taking notes from the science } \\
\text { teacher }\end{array}$ & 22 & 16 & 19 & 43 \\
\hline 22. Reading the science text book & 30 & 19.5 & 36 & 14.5 \\
\hline 23. Copying notes from the board & 10 & 7 & 33.8 & 49.2 \\
\hline 24. Researching on the internet & 70.1 & 13.2 & 9.4 & 7.3 \\
\hline 25. Going on science trips & 88.6 & 7.5 & 2.2 & 1.7 \\
\hline $\begin{array}{l}\text { 26. Having discussions in the } \\
\text { classroom }\end{array}$ & 33 & 19 & 20 & 28 \\
\hline 27. Looking at videos & 79 & 10.3 & 6.4 & 4.3 \\
\hline $\begin{array}{l}\text { 28. Finding the answer to a scientific } \\
\text { problem }\end{array}$ & 44.6 & 22.2 & 19.8 & 13.4 \\
\hline $\begin{array}{l}\text { 29. Working in a group with other } \\
\text { students }\end{array}$ & 67 & 9 & 16 & 8 \\
\hline $\begin{array}{l}\text { Votes. The options were SA ('Strongly } \\
\text { 'Strongly disagree') and D ('Disagree') }\end{array}$ & 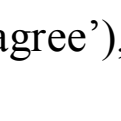 & & & SD \\
\hline
\end{tabular}

From Table (5), it is clear that the most of the learning activities which students use in the classroom to understand science lessons are taking notes from the teacher, reading the science textbook, and copying notes from the board. Most of the students strongly disagree 
that they learn science using the internet, look at videos or work in groups.

7.5 Instructional tools which are used in learning science

\section{Table 6}

The percentage distribution for the students' views about the instructional tools generally used by science teachers in the classroom

$\begin{array}{lll}\text { Percentage of Items } & \end{array}$

responses \%

$\begin{array}{ccl}\text { Yes } & \text { No } & \\ 10 & 90 & \text { 30. Smart board } \\ 100 & 0 & \text { 31. Whiteboard } \\ 21 & 79 & \text { 32. Computer } \\ 38 & 62 & \text { 33. Pictures } \\ 34 & 66 & \text { 34. Data show }\end{array}$

From the finding in Table (6) it is apparent that a majority of the students agree that science teachers always use the whiteboard as an instructional tool to teach science in the classroom and they rarely use other technology tools, such as computers, data show and smart boards.

\subsection{Differences among different groups}

This section will use the T-test to compare the results of students' responses according to gender (boys and girls). The results are shown in Table (7). 
Students' Attitudes and Aspirations

Towards Learning Science at the Secondary Stage in Kuwait

\begin{tabular}{|c|c|c|c|c|c|c|c|c|}
\hline Items & Gender & $\begin{array}{c}\text { Sample } \\
\text { Size }\end{array}$ & Mean & $\begin{array}{c}\mathbf{P}- \\
\text { value } \\
\text { LTV }^{\text {a }}\end{array}$ & T-test & DF & P-value & $\begin{array}{c}\text { Size } \\
\text { Effect }\end{array}$ \\
\hline \multirow{2}{*}{$\begin{array}{l}\text { Students' } \\
\text { views of } \\
\text { science as } \\
\text { a subject }\end{array}$} & Boys & 214 & 3.01 & \multirow[b]{2}{*}{$.000 * *$} & \multirow[b]{2}{*}{4.942} & \multirow[b]{2}{*}{489.0} & \multirow[b]{2}{*}{$.000 * *$} & \multirow[b]{2}{*}{.058} \\
\hline & Girls & 227 & 3.51 & & & & & \\
\hline \multirow{2}{*}{$\begin{array}{l}\text { Students' } \\
\text { views of } \\
\text { science } \\
\text { lessons }\end{array}$} & Boys & 214 & 1.72 & \multirow[b]{2}{*}{$.000 * *$} & \multirow[b]{2}{*}{ 4.271- } & \multirow[b]{2}{*}{466.1} & \multirow[b]{2}{*}{$.000 * *$} & \multirow[b]{2}{*}{.044} \\
\hline & Girls & 227 & 2.06 & & & & & \\
\hline \multirow{2}{*}{$\begin{array}{l}\text { Students' } \\
\text { reasons } \\
\text { for } \\
\text { learning } \\
\text { science }\end{array}$} & Boys & 214 & 1.56 & \multirow[b]{2}{*}{$.000 * *$} & \multirow[b]{2}{*}{ 5.086- } & \multirow[b]{2}{*}{482.0} & \multirow[b]{2}{*}{$.000 * *$} & \multirow[b]{2}{*}{.064} \\
\hline & Girls & 227 & 2.02 & & & & & \\
\hline \multirow[b]{2}{*}{$\begin{array}{l}\text { Students' } \\
\text { views on } \\
\text { the } \\
\text { learning } \\
\text { activities } \\
\text { used in } \\
\text { science } \\
\text { lessons }\end{array}$} & Boys & 214 & 1.62 & \multirow[b]{2}{*}{$.000 * *$} & \multirow[b]{2}{*}{ 4.677- } & \multirow[b]{2}{*}{399.1} & \multirow[b]{2}{*}{$.000 * *$} & \multirow[b]{2}{*}{.052} \\
\hline & Girls & 227 & 2.01 & & & & & \\
\hline
\end{tabular}

$\mathrm{DF}=$ degree of freedom. ${ }^{*}$ The test is statistically significant at the significance level $5 \%$

$* *$ The test is statistically significant at the significance level $1 \%$. a: Levene's test for equality of variance

The finding of the T-test in Table (7) shows that there were significant differences between boys and girls at the significance level $1 \%$ (p-value <.01). The results show that the girls hold more positive aspiration attitudes than the boys to learning science. 


\subsection{Data obtained from interviews}

The sample for the students' semi-structured interviews was 16 students ( 8 boys and 8 girls) in grade ten from different public schools in Kuwait.

\subsubsection{Student attitudes to learning science}

Most of students state that they are not interested in studying science or continuing their study in the science specialty for reasons that they gave, such as that science lessons are mostly difficult, complicated, and that most of the lessons do not provide anything useful for their life. From another point of view, four students say that they will continue their study in the science specialty, and they want to become doctors. These students also agree that some science lessons are difficult and complicated, and they recommend lessons to be made easier, in order to encourage continuation of study on the science path. Some of the students added different views about this point, mentioning that the science classes would be better and more useful if they learnt how they could use science and how it is related to their daily life, by increasing the practical lessons, which would encourage them to continue their study in the science specialty; but using the current methods they think the science is really difficult.

\subsubsection{Students views of science lessons}

Most of the students interviewed agree that most of the science lessons are complicated, difficult, include too much information in each lesson and do not show how useful this science information can be in their daily life. Also, most of students say that the knowledge which they learn in the science classes is not useful to their daily life and they don't know how they will use this knowledge after their school years.

\subsubsection{Science teaching-learning method}

Most of the students interviewed say that they prefer to learn science in practical ways, and with science trips out of the school to visit and see the content information working in reality, and working in groups 
in the science lab to carry out science projects. These students confirmed that these methods of learning science are more enjoyable and these science lessons are more easily understood. However, the students mentioned that these methods are rarely used in science classes in any Kuwaiti schools.

\subsubsection{Students' suggestions to develop science classes}

The students gave some suggestions to develop the science classes in Kuwait, such as to include more practical lessons in the science curriculum, relate the science lessons to the students' needs and their daily life, make science lessons easier rather than complicated, and use practical methods in class.

\section{Discussion}

The results of this study show that most of the students have negative attitude toward learning science and don't want to continue their study in the science specialty. These views come from both boys and girls, but perhaps the girls have a slightly more positive attitude toward science. The results show that the science lessons are currently boring and difficult to understand, with content lacking in interest and unhelpful for application in everyday life. The findings indicate that most students are not interested in becoming scientists and do not prefer science as a study subject. The students suggested some ways to develop their science learning, such as adding more practical lessons, relating the science lessons to their daily life problems, and limiting the range of the science lessons.

The explanation of the above results about the negative attitude of students to science lessons and to continuing their study on the science path may be for various reasons, including that these science lessons do not relate to their daily life and needs and do not equip them to use science to resolve their problems. Also, the teaching methods used in the science lessons are not interesting for these students because they prefer practical methods of learning science. In addition, the large amount of information makes science lessons 
complicated and therefore affects the students' attitude toward science.

This argument is made and agreed with by some studies such as BouJaoude and Gholam (2013), Riess, (2010), Han (2017), and Nadi and Ali (2017), which affirm the importance of taking the students' needs, preferences and interests into account when the science curriculum and lessons are reformed, and that this will have a positive effect on students' attitude toward science. 


\section{$\underline{\text { References }}$}

Al-Daami, K., Wallace, G., (2007) Curriculum Reform in Global Context: a Study of Teachers in Jordan. Curriculum Studies, Vol. 39, (3), 339-360.

BouJaoude, S., \& Gholam, G. (2013). Gender and science in the Arab states: current status and future prospects. In Mansour, N. \& Wegerif, R. (Eds.). Science Education for Diversity in the Knowledge Society: Theory and Practice, (pp. 339-358). New York: Springer.

Catherine H., Panchompoo W, Ming C and K. Ann Renninger (2018). Life science students' attitudes, interest, and performance in introductory physics for life sciences: An exploratory study. Published by the American Physical Society.

Central Statistical Bureau in Kuwait (2018). Annual Bulletin of Education Statistics.

Cerini, B., Murray, I. and Reiss, M. J. (2003). Student Review of the Science Curriculum: Major Findings. London: Planet Science.

Gall, M. D., Gall, J. P., \& Borg, W. R. (2006). Educational research: An introduction (8th edn). Boston: Allyn \& Bacon.

Gilbert, W. (2010). Developing Culturally Based Science Curriculum for Native American Classrooms. In Reyhner, J., Gilbert, W. S. and Lockard, L. (Eds). (2011). Honoring Our Heritage: Culturally Appropriate Approaches to Indigenous Education (pp. 43-55). Flagstaff, AZ: Northern Arizona University.

Fullan, M. (2007). The new meaning of educational change (4th ed.). New York, NY: Teachers College Press.

Han, S. (2017). Korean students' attitudes toward STEM project- 
based learning and major selection. Educational Sciences: Theory \& Practice, 17, 529548.http://dx.doi.org/10.12738/estp.2017.2.0264

Idris, F., Hassan, Z., Ya'acob, A., Gill, S., Aziah, N., \& Awal, M., (2012). The role of education in shaping youth's national identity. Social and Behavioral Sciences, 59, 443-450.

Jackson, D. (2005). Why Pupils' Voice? Facilitating Pupil Involvement in Learning Networks, NCSL.

Johnson, R. B., \& Onwuegbuzie, A. J. (2004). Mixed methods research: A research paradigm whose time has come. Educational Researcher, Vol. 33, No. 7, 14-26.

Khan, S. (2010). Education and agency: Muslim women and the tensions of traditional and modern expectations. (Dissertation.) Harvard University, USA.

Leat, D., \& Reid, A. (2012). Exploring the role of student researchers in the process of curriculum development. Curriculum Journal, 23:2, 189-205.

Lemke, J. L. (2001). Articulating communities: Socio-cultural perspectives on science education. Journal of Research in Science Teaching, 38(3), 296-316.

Levin, B. (2000). Putting Students at the Centre in Education Reform. Journal of Educational Change, 1,(2), 155-172.

Manefield, J., Collins,R., Moore,J., Mahar,S. \& Warne C. (2007). Student Voice: a historical perspective and new directions. Department of Education, Melbourne.

Mansour, N. (2013). Modelling the Sociocultural Contexts of Science Education: The Teachers' Perspective. Research in Science Education. 43:347-369.

Minister of Health in Kuwait interview (2018). Published in the Alqabas newspaper on 02.10.2017 
Nadi, S. Ali, M. ( 2017). Pre-service teachers attitudes toward teaching science and their science learning at Indonesia open university. Turkish Online Journal of Distance Education-TOJDE October 2017 ISSN 1302-6488 Volume: 18 Number: 4 Article 5.

Reiss, M. J. (2002) Reforming school science education in the light of pupil views and the boundaries of science. School Science Review, 84(307), 71-77.

Reiss, M. J. (2006) Listening to pupils. In: What is Science Education For?, Gilland, T. (Ed.), London, Academy of Ideas, pp. 41-46.

Reiss, M. J. (2010). Science and religion: Implications for science educators. Cultural Studies of Science Education, 5(1), 91-101.

Shah, R. (2012). Goodbye conflict, hello development? Curriculum reform in Timor-Leste. International Journal of Educational Development, 32, 31-38.

Statistic Education Ministry of Kuwait about the Teachers in Kuwait (2018). Published by Alseyassah newspaper on 212- 2018.

Van den Akker, J.J.H. (2003). Curriculum perspectives: an introduction. In J. van den Akker, W. Kuiper \& U. Hameyer (Eds), Curriculum landscape and trends. Dordrecht: Kluwer Academic Publishers.

Waldrip, B. G., \& Taylor, P. C. (1999). Permeability of students' worldviews to their school views in a non-Western developing country. Journal of Research in Science Teaching, 36, 289-303. 